\title{
DEVELOPING A MODEL OF SMART SCHOOL CANTEEN: AN INTRODUCTION OF SELF-PURCHASING TECHNOLOGY
}

\author{
Andri Zainal $^{1}{ }^{*}$, Tuti Sriwedari ${ }^{1}$, Khairunnisa Harahap ${ }^{1}$, Joko Suhariyanto ${ }^{1}$ \\ ${ }^{1}$ Department of Accounting, Faculty of Economics, Universitas Negeri Medan, Medan, Indonesia \\ *Corresponding Author: andrizainal@unimed.ac.id
}

\begin{abstract}
In general, the development of character building in a formal education can be applied through buying and selling transaction activities in the school canteen. The widespread use of computer technology can also be applied in trade activities in school canteens as an effort to establish the character of Indonesia's young generation with integrity and honesty. The introductory on the use of technology through a Self-Purchasing System or also commonly known as the Self-Check-out System is a mechanism that provides an opportunity for customers to process their purchases by scanning the items they buy and making direct payments before leaving the store/store. This technology can be initiated into religious and non-religious-based elementary schools that practice the values integrity and honest character from a specific religion to general values. However, even though these values have become a daily part of learning, the use of modern technology in the practice of education cannot be denied. Thus, the combination of pedagogy on the conceptual character-building value in the classroom and the use of science and technology in trading activities in the school canteen will accelerate the formation of integrity and honest character within the pupils.
\end{abstract}

Keywords: Character Building, Self-Purchasing System, Governance, Smart School Canteen Model.

\section{INTRODUCTION}

Character formation should not take place instantaneously, the results can be seen in plain view after the character formation process is carried out. The formal character formation process generally starts from education in elementary school to the tertiary level. In particular, regarding the efforts of the Government of the Republic of Indonesia in reducing the number of acts of corruption, the role of formal education in shaping the character of superior resources with integrity and honesty is crucial. This has been underlined by Schweinhart (1994) in Megawangi (2004) that planting honest character from an early age at the elementary school level is one of the most effective efforts that determine the success of expected outcomes in the long run. Furthermore, the effectiveness of the intended outcomes is determined by the application of an educational model that is relevant to their development period, namely by using the game as a medium for transferring knowledge specifically to build an understanding of honesty in the early stages.

In general, character building activities in formal education can be applied through buying and selling transaction activities in the school canteen. The touch of science and technology (science and technology) can also be applied in trade activities in school canteens in an effort to establish the character of Indonesia's young generation with integrity and honesty. The introduction of the Self-Purchasing System technology, also known as the Self Check-out System, is a mechanism that provides the opportunity for customers to process their purchases by scanning the items they buy and making direct payments before leaving the store/store (adapted from the article "Self -checkout "inside https://en.m.wikipedia.org/wki/Self-checkout).

As stated by Dewey (2004) that the principle of health education is based on experience that allows students to experience the values taught, both when they become subjects and objects that are obtained when they do, see or even hear during the process. Thus, the achievement of the character of honesty in the format of learning products will be embodied through understanding (cognitive), attitudes (affective) and behavior (psychomotor) that reflect integrity and honesty in a simple but very applicable pattern offered by the utilization of this Self Purchasing System Science and Technology. The students will be accustomed to being orderly, trustworthy and responsible for the items they buy both without and with supervision from the canteen guard. On the other hand, students will also become civil and independent and minimize the risk or loophole of fraud that can occur in a conventional expenditure system when the cashier must serve his customers at the same time. 


\section{URGENCY OF IMPLEMENTING SMART CANTEEN PROGRAMS}

The use of appropriate technology should be able to be started for students in elementary schools that target the improvement of financial and managerial technology literacy of students targeted by beneficiaries. In particular, this increase in literacy is expected to equip students to be more adaptive in the development of information technology. ) in higher education. In relation to financial managerial lioterization, the education of effective canteen-based school canteen management will be the foundation for the creation of future financial planners who apply the principles of financial risk and discipline in financial spending.

Table 1. Problems of Priority and Solutions for School Canteen Management

\begin{tabular}{|c|c|c|}
\hline No. & Priority Issues & Solutions \\
\hline 1 & $\begin{array}{l}\text { a) Increasing information technology } \\
\text { and managerial financial literacy } \\
\text { from an early age. } \\
\text { b) The trading system in the canteen is } \\
\text { done conventionally. }\end{array}$ & $\begin{array}{l}\text { - The adoption of a computer-assisted Self Purchasing / Check- } \\
\text { out System technology, a scanner, and a modified receipt } \\
\text { printer. } \\
\text { - Presentation of financial risk material for early childhood } \\
\text { based on interactive multimedia. }\end{array}$ \\
\hline 2 & $\begin{array}{l}\text { Street vendors sell food/beverage } \\
\text { packaging and ready-to-eat products on } \\
\text { the edge of public roads outside the } \\
\text { school building. }\end{array}$ & $\begin{array}{l}\text { Introduction and trial of the Merchandise Management Model } \\
\text { sold by street vendors in an integrated manner in the School } \\
\text { Canteen. }\end{array}$ \\
\hline 3 & $\begin{array}{l}\text { Introduction and trial of the } \\
\text { Merchandise Management Model sold } \\
\text { by street vendors in an integrated } \\
\text { manner in the School Canteen. }\end{array}$ & $\begin{array}{l}\text { a) Dissemination to street vendors in the adoption of a } \\
\text { consignment system of goods sold to be offered centrally in } \\
\text { the school canteen. } \\
\text { b) Management of merchandise assistance as a pilot for business } \\
\text { entities for local street vendors. }\end{array}$ \\
\hline
\end{tabular}

\section{PROPOSAL OF THE IMPLEMENTATION METHOD}

The structure of the implementation of Smart Canteen activities based on the Self-Purchasing System is described in Table 2 as follows:

\begin{tabular}{|c|c|c|c|c|}
\hline & Stages of Activity & Approach Method & Partner Participation & Target / Output \\
\hline I. & $\begin{array}{l}\text { Pre-Study: Initial } \\
\text { observation of the } \\
\text { location of prospective } \\
\text { beneficiaries: Selected } \\
\text { schools }\end{array}$ & $\begin{array}{l}\text { Conduct field observations } \\
\text { and interviews with } \\
\text { representatives of both } \\
\text { partners: Principal and } \\
\text { Canteen Guard }\end{array}$ & $\begin{array}{l}\text { Prepare data and personnel for in- } \\
\text { depth interviews and meeting } \\
\text { rooms }\end{array}$ & $\begin{array}{l}\text { Partner profile, } \\
\text { problem identification, } \\
\text { initial documentation }\end{array}$ \\
\hline II. & $\begin{array}{l}\text { Solution Formulation: } \\
\text { Focus Group } \\
\text { Discussion (FGD) } \\
\text { internal proposal team } \\
\text { and between the } \\
\text { proposer team and } \\
\text { partner representatives }\end{array}$ & $\begin{array}{l}\text { FGD among the proposing } \\
\text { team } \rightarrow \text { Applicative } \\
\text { solutions to overcome } \\
\text { partner problems }\end{array}$ & $\begin{array}{l}\text { Partners provide responses } \\
\text { regarding the feasibility of the } \\
\text { solutions offered by the proposal } \\
\text { team to obtain agreement points } \\
\text { regarding the format and } \\
\text { mechanism for implementing the } \\
\text { solution in question. }\end{array}$ & $\begin{array}{l}\text { Understanding of the } \\
\text { format and mechanism } \\
\text { for implementing the } \\
\text { solution. }\end{array}$ \\
\hline III. & $\begin{array}{l}\text { Procurement of TTG } \\
\text { Self Purchasing System } \\
\text { and Technology-Based } \\
\text { School Canteen } \\
\text { Management } \\
\text { Assistance. }\end{array}$ & $\begin{array}{l}\text { Installation, demonstration, } \\
\text { trial, and handover of TTG. }\end{array}$ & $\begin{array}{l}\text { 1) Bring participants: } \\
\text { a. Teacher } \\
\text { b. Students } \\
\text { c. Local street vendors. } \\
\text { 2) Providing supporting } \\
\text { facilities and infrastructure: } \\
\text { meeting rooms, audio-visual } \\
\text { equipment, tables, and chairs. }\end{array}$ & $\begin{array}{l}\text { a. Handover document } \\
\text { for TTG } \\
\text { b. Module and } \\
\text { operational } \\
\text { procedures for the } \\
\text { Canteen Self } \\
\text { Purchasing System }\end{array}$ \\
\hline IV. & $\begin{array}{lr}\text { Assistance } & \text { in } \\
\text { Integrating } & \text { School } \\
\text { Canteen Services with } \\
\text { Empowering Local } \\
\text { Street vendors. }\end{array}$ & $\begin{array}{l}\text { Information dissemination } \\
\text { and School Canteen } \\
\text { Operational Management } \\
\text { and FGD involving local } \\
\text { street vendors. }\end{array}$ & $\begin{array}{l}\text { 1) Bring participants: } \\
\text { a. School Representative. } \\
\text { b. Local street vendors. } \\
\text { 2) Providing supporting } \\
\text { facilities and infrastructure: } \\
\text { meeting rooms, audio-visual } \\
\text { equipment, tables, and chairs. }\end{array}$ & $\begin{array}{l}\text { The formation of a } \\
\text { PKL business group } \\
\text { team as a pilot for } \\
\text { economic institutions }\end{array}$ \\
\hline
\end{tabular}


Schematically presented in Figure 1 below:
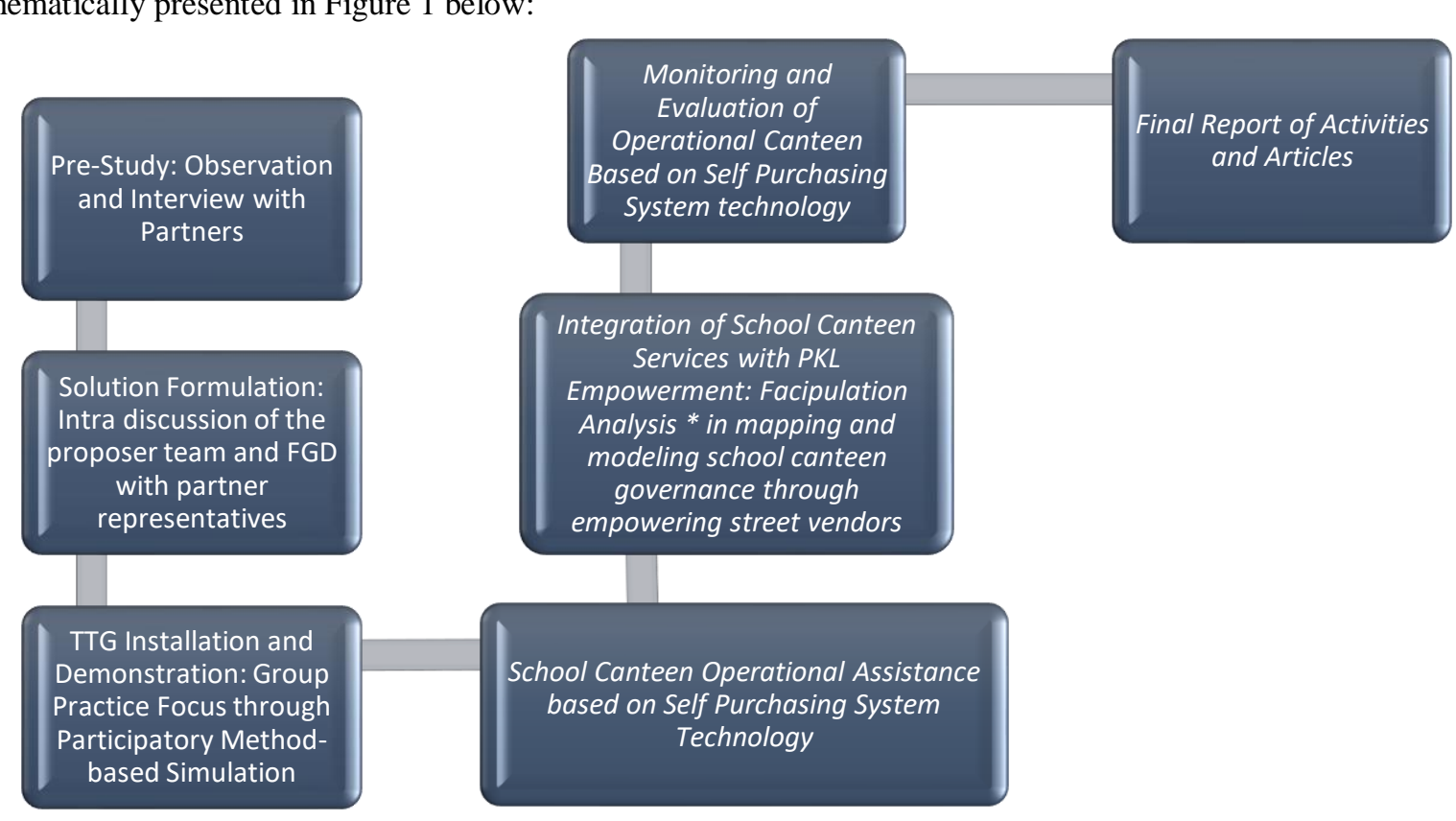

* Facipulation Analysis is an analysis that combines facilitation techniques and alternative "manipulation" of action by involving users in discussions for the formulation of mapping and final action modeling according to existing situations and conditions (adapted from Facipulation - The Background article by Paul Levy, available at http://www.amed.org.uk/forum/topics/facipulation-the-background)

Figure 3. Flow of Implementation of Community Partnership Program Activities

\section{CONCLUSIONS AND IMPLICATIONS}

The Smart Canteen development program is one of the strategic efforts for the growth of the character of honesty and integrity especially for students starting from an early age and basic level. This activity needs to be followed up by combining scientific research methods based on facipulation analysis techniques with an actualization approach to community service programs simultaneously. Specifically, the implementation of this activity is expected to lay a solid foundation for early age students through the implementation of the Smart Canteen program in a non-formal format but still thick with educational nuances. On the one hand, the achievement of the activities will be able to develop the character of integrity within themselves and on the other hand, it is expected to strengthen the spirit of independence and readiness of the nation's children, especially related to the mastery of information technology in the era of industrial revolution 4.0 today.

\section{REFERENCES}

Dewey, J. (2004). Experience and Education: Pendidikan berbasis pengalaman. (Alih Bahasa Hani'ah). Penerbit Taraju: Jakarta.

Megawangi, R. (2004). Pendidikan Karakter; Solusi yang Tepat untuk Membangun Bangsa.Bogor:Indonesia Heritage Foundation

Scweinhart, L. J. (1994). The lasting benefits of preschool programs. Urbana, IL: ERIC Clearinghouse on Elementary and Early Childhood Education. (ERIC Identifier: ED365478). 